\title{
IN MEMORIAM: WALTER KRIVDA (1932-2018)
}

Robert Wrigley

505 Boreham Blvd.

Winnipeg, MB R3P OK2

robertwrigley@mts.net

Terry Galloway

Department of Entomology

University of Manitoba

Winnipeg, MB R3T 2N2

Terry.Galloway@umanitoba.ca

Michael Leblanc

136 Jefferson Ave.

Winnipeg, MB R2V $0 \mathrm{M} 1$

Walter Vladimir Krivda was born of Ukrainian parents in The Pas, Manitoba in 1932. During childhood and teenage years, Walter was fascinated with Nature and could often be found catching insects, pressing plants, picking mushrooms, and wandering through the fields and forests around his home. Describing himself as a timid young boy and speaking no English, he had a difficult time in school at first, but his language skills improved rapidly when he later transferred to a Catholic school, where classes were conducted in both French and English. After graduating from high school in 1952, Walter was hired at the Entomological Research Station in Ottawa, which greatly increased his knowledge of insects (Figure 1). He later pursued his education by attending United College (now the University of Winnipeg) and the University of Ottawa, where he graduated in 1954. His first job was teaching school (the only teacher for all nine grades) at Gillam, Manitoba, located at Mile 326 on the Hudson Bay Railway. The town consisted of only one street and wolves were frequent visitors, as evidenced by tracks in the snow and their nightly howling.

In the following years, Walter taught at Hecla and Virden, Manitoba, and in 1961, he became the first

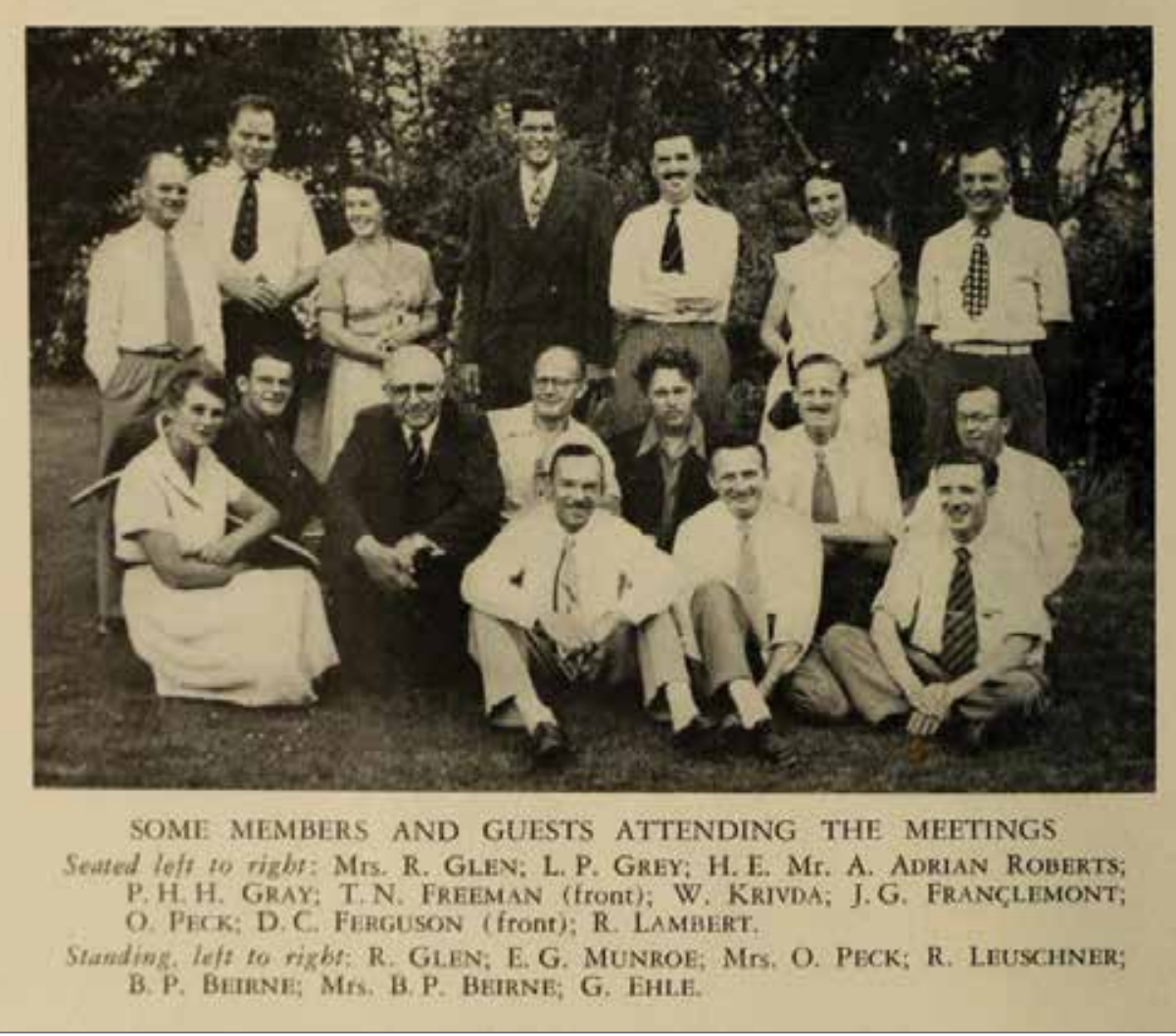

FIGURE 1. Walter Krivda (middle row, kneeling, with long black hair) attending the 3rd Lepidopterists Society meeting held in Ottawa in July, 1952 (photographer unknown). Photo courtesy of Michelle Locke and Vazrick Zazari (Canadian National Collection of Insects, Arachnids and Nematodes, Agriculture and Agri-Food Canada, Ottawa).

Park Naturalist for Riding Mountain National Park, headquartered at Wasagaming, Manitoba. In 1965, he transferred to Prince Albert National Park with an office at Waskesiu, Saskatchewan. At both locations, he documented plant and animal life, preserved natural history specimens, prepared interpretive programs and displays, and gave lectures and nature tours for the public.

Walter's next position was with the Canadian Wildlife Service in Edmonton, where his work focused on identifying plants and lichens related to big-game feeding habits. He apparently missed teaching because he accepted the position of Supervisor of Extension Services at the Vocational Centre in The Pas, which evolved into the Keewatin Community College. Walter taught numerous courses over four decades, with one of his favourites being the Adult Basic
Education Course, which prepared students, who had been away from school for some time, to attend full-time college. Even in retirement, he continued tutoring students and encouraging in them an interest in biology. In 1970, Walter was awarded a Manitoba Centennial Medal by the Manitoba Historical Society for his "contributions to Manitoba in the teaching profession and for his many years of research in natural history and work for museums." Walter was particularly active with the Sam Waller Museum in The Pas. He was well known to the staff and readers of the Opasquia Times newspaper in The Pas through his articles, such as his 2008 recommendation to band trees to protect them against cankerworms; of course, he took this as an opportunity to describe the entire life cycle of the moth.

Wrigley first met Walter back 


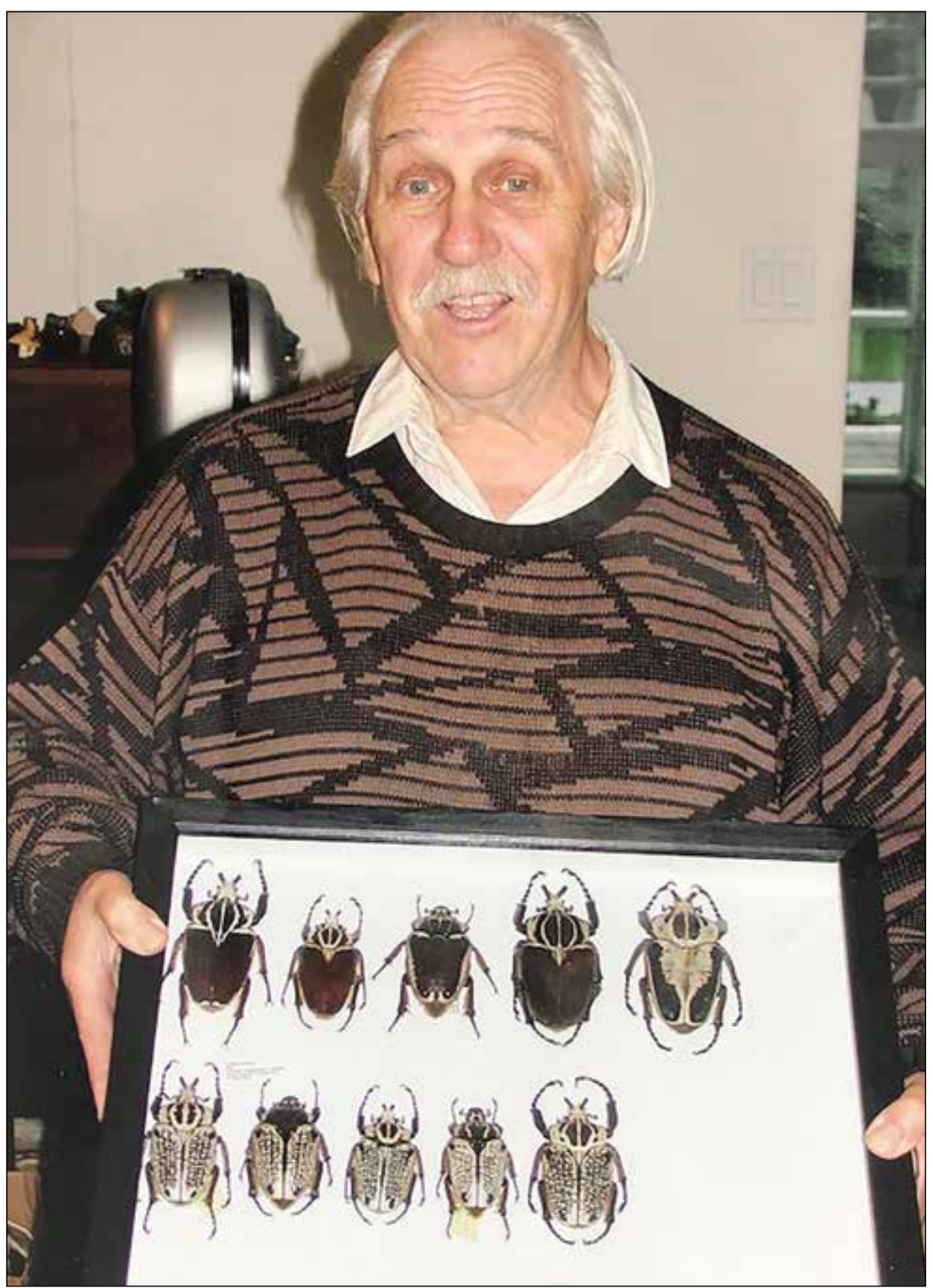

FIGURE 2. Walter posing with a tray of goliath beetles during a visit to Robert Wrigley's Winnipeg home in 2014. Photo credit: Robert Wrigley.

in the early 1970s during Walter's occasional visits to the Manitoba Museum, where he spent the day happily perusing the research collections of plants and insects, and determining the identifications of his specimens. In later years, he sent in bottles of beetles from The Pas area (with Walter's penchant for thrift, preserved in mouth wash), which Wrigley mounted and deposited into the J.B. Wallis-R.E. Roughley Museum of Entomology. Walter frequently requested entomology books and spare beetle specimens so that he could teach local youth how to prepare and identify specimens, in the hopes they would take an interest in entomology (Figure 2). While interested in diverse natural history subjects, two of his favourite projects were raising wasps from galls and tending varieties of garden plants. He encouraged Wrigley to plant his huge fava beans, a variety he emphasized were brought by his parents from the Old Country; he said they were excellent in soups (and they were).
One of Walter's routines during the warmer months was to check out the street lights each evening for unusual moths. He corresponded frequently with scientists in Ottawa regarding the identifications of insects and plants, and recorded a number of distributional records of species from The Pas. Walter was eager to share his exciting discoveries, and consequently, he frequently published his research, ranging from slugs and fungi to butterflies and shrews, in the Blue Jay - the journal of Nature Saskatchewan. Over the decades, Walter accumulated vast collections of plants, moths, butterflies, beetles, and small mammals.

Unable to type letters or labels, Walter's handwriting style was notoriously challenging to decipher, so his occasional letters required some time and effort to interpret. However, he could readily talk on the phone for an hour or more, jumping from one topic to another, such as classical music, ancient history and his family recipes. He was the ultimate storyteller, with a breadth of knowledge (largely self-taught) that was truly impressive. Known to children of The Pas area as 'Santa,' and to adults as 'Uncle Walter,' he was recognized as a pillar and legend in the community. Kind, gentle, and generous of nature, he was quick to offer greetings to people on the street, and often handed fresh fruit and preserves from his garden to anyone walking by his home. Walter passed away on September 17, 2018 at the age of 86 years. He will be missed by his many friends in The Pas, and by his natural history colleagues down south.

Michael Leblanc grew up in The Pas where Walter was a long-time friend of the family. Every Thursday night, Walter came by the house and - over tea, crackers, and preserves - he would discuss insects, life, and solve the world's problems. Walter was always willing to share information freely, and especially loved discussing 
entomology. He was also very well versed in what was edible in the bush, and conducted many field trips with students and anyone else who wished to learn. He taught what mushrooms, berries, and other plants were good to eat, and then picked certain leaves for making tea.

Walter loved to teach and expand people's minds, loved his entomology and his insect collection, and his large collection of books of which he had no doubt read each one. Even in the hospital, a few weeks before his death, he was still trying to teach, regaling visitors during their hospital visits, including Michael's son Riley, with stories about the history of The Pas. Walter was full of knowledge and willing to share it with anyone willing to listen. His loss is more than just a loss of a good man, but the loss of a lifetime of knowledge. Even though Riley only met Walter shortly before his death, he knew Walter through the stories his family would tell him. Riley's love for entomology was enhanced by the knowledge Michael gained from Walter. Walter will be missed.

We wish to thank to Michelle Locke and Vazrick Nazari (CNC) for submitting a photograph of Walter, and Sharain Jones (Museum Director, Sam Waller Museum, The Pas) for directing the authors to the following publication: Krivda, W. 1983. In; The Pas Gateway to Northern Manitoba. The Pas Historical Society, The Pas, Manitoba. pp. 312-314.

https://digitalcollections.lib. umanitoba.ca/islandora/object/ uofm\%3A2278811\#page/326/mode/1up (accessed October 23, 2018).

\section{Krivda's publications in Blue Jay}

1960. A record of Boloria toddi toddi double-brooded in The Pas, Manitoba. Blue Jay 15(4):181.

1973. Macoun's Arctic in central Canada. Blue Jay 31(3):184-185.

1974. (with W.J. Cody). Carex maritima Gunn. An adventive sedge at The Pas, Manitoba. Blue Jay 32(1):25-26.

1974. A white-banded say sphinx moth - new to Manitoba. Blue Jay 32(1):32.

1976. Movement in spring peepers. Blue Jay 34(1):17.

1976. Additional Manitoba records of the short-tailed shrew. Blue Jay 34(2):116.

1979. Colias christina habitat destroyed at The Pas, Manitoba. Blue Jay 37(2):89.

1979. Euptoieta claudia in Manitoba. Blue Jay 37(4):200-201.

1980. House sparrows feeding on Malacosoma moths. Blue Jay 38(3):189-190.

1981. The pearly eye at The Pas, Manitoba. Blue Jay 39(2):82.

1981. Hibernating bumble bees at The Pas, Manitoba. Blue Jay 39(4):195.

1982. Giant water beetles at The Pas, Manitoba. Blue Jay 40(1):15.

1982. Fungi preserving. Blue Jay 40(2): 72.

1982. White-faced queen wasp attacks crane fly at The Pas. Blue Jay 40(3):153.

1983. Dispersal of the pearly eye at The Pas, Manitoba. Blue Jay 41(1):8.

1983. The rare Epirrhanthis geometer moth at The Pas, Manitoba. Blue Jay 41(3):141.

1984. Manitoba records for showy aster. Blue Jay 42(2):70.

1985. Chinese elm - a new food plant for the mourning cloak butterfly. Blue Jay 43(2):130.

1985. Sudden disappearance of morels at The Pas, Manitoba. Blue Jay 43(3):150.

1986. Ghost moth in spider web at The Pas. Blue Jay 44(1):5.

1986. Variegated fritillary breeding at The Pas, Manitoba. Blue Jay 44(3):166-167.
1987. American carrion beetle rare at The Pas, Manitoba. Blue Jay 45(1):3.

1987. The sticky groundsel at The Pas, Manitoba. Blue Jay 45(3):145.

1988. A rare migrant California tortoise shell butterfly at The Pas, Manitoba. Blue Jay 46(2):75.

1991. Mummified bats at The Pas. Blue Jay 49(2):105.

1993. Road kills of migrating garter snakes at The Pas, Manitoba. Blue Jay 51(4):197-198.

1997. Road kills of migrating garter snakes at The Pas, Manitoba. Blue Jay 55(2):137.

2001. Yellow underwing (Noctua pronuba), a new moth in Manitoba. Blue Jay 59:206.

2001. House sparrow swiftly kills and eats Catocala moth at The Pas, Manitoba. Blue Jay 59:210.

2002. European skipper at The Pas, Manitoba. Blue Jay 60:183.

2002. Common roadside skipper vanishes at The Pas, Manitoba. Blue Jay 60:226.

2003. Compton tortoiseshell deaths in abandoned cars. Blue Jay 61:126.

2004. Copper underwing at The Pas, Manitoba. Blue Jay 62:47.

2006. Large earthworm at The Pas, Manitoba. Blue Jay 64:112.

2006. Net butterfly records. Blue Jay 64:113.

2006. Crested shield fern (Dryopteris cristata) at The Pas, Manitoba. Blue Jay 64:173.

2007. European skipper population explosion at The Pas, Manitoba. Blue Jay 65:168.

2008. Pink lady's slipper population at Reed Lake, Manitoba. Blue Jay 66:52.

2008. Showy lady's slipper, Cypripedium reginae, in disturbed habitat at The Pas, Manitoba. Blue Jay 67:178.

2011. Slugs as a control measure for burdock at The Pas Manitoba? Blue Jay 69(3):130.

2014. $99 \%$ population crash in grass moths (Crambus sp.) at The Pas, Manitoba. Blue Jay 71(1):60. 